\title{
The kinetics of pension economics along with its consequences and necessity of proper role and long-term commitments from the government of Bangladesh
}

\author{
Mahfuz Ibn Mannan \\ Department of Natural Sciences, University of Information Technology \& Sciences (UITS), Bangladesh
}

\begin{abstract}
This paper works on the contemporary haphazard activities, technical limitations, misleading set of requirements, and lack of regular addressing by many external auditors in relevant accounting standard-IAS19 with respect to Employees' Benefit Fund and manifests irrationalities, under-proportional issues in respect to different employees' benefit schemes including long-term financial hazards along with risk of capital market investors based on financial analysis. The paper is underpinned with the couple of case studies with different nature of offices of non-government and government and points out from the extractions of the studies that the short-comes of practice drives the pension economics is not working diligently. Finally, the paper having an indicative role to the relevant policy makers of the government in Bangladesh to pay attention to take necessary potential measures in employee benefit industry to overcome from current intertwined circumstance aiming the sustainable pension economics could go forward in the line of continuing macro economic development of Bangladesh and starting work to engage at least one government body temporarily as regulator until an independent and complete regulator forms as per jurisdiction as well as commitments to the report produced by external auditors through clearly stating the activities and status taken by enterprises in the light of IAS 19/BAS 19 in the report on regular basis.
\end{abstract}

Key Words: Accounting Standards, Actuarial Assessment, Gratuity, Pension, Risk

\section{Introduction}

Employees benefit schemes like pension, gratuity etc are not something choice of employer rather these are legal right of employees to the employer that is given for his/her contribution of entire golden lifetime to the employer. Hence, this is obligatory for the employer to go consistent with requirements set within accounting standard (IAS 19) during annual audit. It is expected that the employer remain responsive and committed in respect to these types of benefits through required provisioning time to time under supervision by the trustee board as these benefits are Defined Employees' Benefit.

Besides, this kind of funds like pension is a great source of development of national savings and investments. It serves national purpose by channelizing the amount of large number of employees, accumulating them and making them available for proper investment in national development activities from macro-level view point, even during unexpected financial crisis government could utilize this huge fund and counter-acts inflation and plays a vital role in stabilizing and building national economy, and intervene the liquidity in the economy. This systematic pension fund can also play a greater role systematically in an economy for developing countries, like Bangladesh where capital is shy, rate of savings is very low i.e. (bellow $7.5 \%$ of GDP) investment opportunities are still lacking, severe inflationary climate prevails, and solid social security of the people are readily absent.

In this tune, a proper, systematic and sound national action plan and its implementation over this type of giant fund is a very important for manifold activities and operations such as securing the right of employees in first, setting pool of investments for long term in the second intervening the liquidity etc. as all these activities lay within a pension economics for macro purposes.

\subsection{Methodology:}

Required information has been collected from both primary and secondary sources. Primary data was collected from dedicated departments of the office, like Human Resource department, Accounts department, Finance department, trustee member, top management personnel etc as the dedicated persons from these departments are mostly linked to the pension, superannuation, gratuity schemes. The sources of secondary information include relevant office circulars, announcements, books, journals, newspapers, valuation reports, accounting standard book and so on.

\subsection{Objective:}


The main goal of the study is to evaluate concurrent condition and practice, limitations, challenges for existing employee benefit system and then draw instructions on it for Bangladesh circumstance. The study has been carried out with the following objectives:

i. To evaluate the existing nature of practice and awareness with short comes/drawbacks in Bangladesh

ii. To identify the contemporary challenges at hand in Bangladesh

iii. To make some instructions/recommendations/suggestions to get rid from these routine problems in employee benefits for Bangladesh.

\section{Body}

The body comprises two relevant case studies of first one on gratuity in private enterprises and then the pension issue for government offices including authorities, corporation, commissions, etc.

These are many private organizations and enterprises along with giant group of companies with more than a decade operation life time. In customized way they belong to a range of industries like banking, nonbanking financial institution, life insurance, general insurance, real estate, pharmaceuticals, garments, textile, multi-national companies etc. Many of them are listed in the capital market at where the Bangladesh Security and Exchange Commission (BSEC) is the regulator. In financial activities, the Bangladesh Bank (BB) plays the regulatory role. There are some other regulators regulate specifically industry-wise as relevant for example the Insurance Development and Regulatory Authority (IDRA) for the insurance industry. For all these kind of private offices gratuity is supposed to be the most common employees' benefit scheme besides provident fund activities. Idiosyncratically, many of them have no separate trustee and/or separate gratuity fund. Also many of continuing non-unique and non-rationale and poor benefit scheme in absence of local regulations. Besides, There are a very few companies which maintain superannuation fund for their employees in parallel to gratuity, but the operation of that scheme is not that known so far.

\subsection{Extract from Case Study on Private Enterprises:}

This case study is made from the basis of multi-office (private like banks, group of companies some of which are listed in capital market some others are not) investigation. There are a couple of groups introduced to point out the entire practice. The first kind of offices are doing business for more than a decade with the registration from Registrar of Joint Stock Companies and Firms (RJSC) have no that gratuity fund but the provident. The second kind has trustee but the gratuity fund is not separate. The third kind illustrates having separate gratuity fund but is not assessed on regular basis then is not addressed and covered as per BAS 19 by many external auditors in many companies. The forth mentionable kind is those offices which has separate fund via separate account, governed by trustee addressed by external auditors regularly but actuarial valuation takes place once in 3 years and in most cases fund is found a significant shortfall, and the scheme asset is invested to the same enterprises business leaving the asset jeopardized as the balance sheet of that question enterprise is found hardly apparent from investment point of view with financial analysis but trustee do its asset threatening. The most reputed multi-national companies are found sound and fulfillment to the compliance at IAS 19. There are few domestic companies which are also compliance under IAS19 as those companies have an objective to issue bond or would like to raise loan from the market. But, one point is common irrespective to groups and nature of the companies that is the membership data (employees data) and its viability is still a big question as it is very sensitive to the actuarial liabilities amount and so the status of the fund shortfall or surplus is determined through. It is found in many cases that in private sector most of the data fails during validity check. This means there is an essential need of scope to become sure of the supplied data from the enterprises as these membership data are true and fit for the purpose. The fact is the actuarial liability figure of the employees' benefit fund like gratuity and/or superannuation fund for the most of the private offices based on their supplied data are hardly apparent to actuaries from their experience. Also, there is another short comes that is if any employee works in ' $\mathrm{X}$ ' company for 4 years and then switch to ' $\mathrm{Y}$ ' company his first 4 years' service length value is not addressed by the second company, and the employee becomes sufferer.

There are a good number of government bodies like corporations, authorities, commissions etc exist at where provident fund exists for their employees but gratuity is not everywhere. These funds are mostly managed under budgetary frame work of the government. As the benefit schemes are defined benefit plan by nature and government contributes at the fund on regular basis as calculated by auditors to the said funded benefit. Pension is also defined here but, pension is comparatively rare in government offices (corporation, commissions, authority etc) than the gratuity. The practice is if any government office eager to launch pension scheme then government requires that the said office is to be sufficiently solvent to operate that pension fund along with its expenses from its own income. There is a set of requirements from the government through the Ministry of Finance (MoF), Bangladesh for these interested offices to propose a pension scheme via auditing asset by external auditor and liability by actuarial firms separately as per set guide lines under Reference-11 and then fill 
some 3 tables from the extract of these auditor's and actuarial reports and send those tables along with audit and actuarial reports to the MoF's dedicated relevant office for approval.

Furthermore, in the starting of 2014 government started a new commission to deal with the salary of the government employees naming Pay Commission. This commission is the key responsible to set consistent and proportional salary frame work in course of time. But, there is no other government body who will deal the future outcome of this update salary in the form of pension or likely employees' benefit scheme which is a crucial component of macro financial and economic policy in the national scale.

\subsection{Extract from Case Study on Government Offices:}

All the government offices are not acting under the same employees' benefit scheme requirement. For example the government bank employees' benefit schemes are apart from government corporation offices.

In government offices, there are different types of employee benefit exists those are superannuation or pension, gratuity, and/or provident fund under budgetary framework. As on now most of the government offices has no pension fund. Some of them have been maintaining provident fund only and other both gratuity and provident fund. But this gratuity fund asset for many government offices are not expected to be solvent due to lack of actuarial analysis and then uncovered by under BAS 19 groundling. Many government offices believe that they have sufficient income to introduce pension for the employees irrespective to whether they already have gratuity. But this transformation subjects to fulfillment of the set requirements by the Ministry of Finance (MoF), Bangladesh to the full. But, these requirements are not that apparent from technical point of view and misleading in some sense and hence accumulating a long-term huge financial risk to macro economy. The requirement comprises 10 points out of which 4 are to be done as per actuarial approach. The requirements set for actuarial professionals are (1) Actuarial liability of existing Gratuity Fund (if any) as at set date of valuation along with expected Future service cost for future 10 years (to be mentioned as in attached Table-1), (2) Actuarial liability of proposed Pension Fund as at set date of valuation along with expected Future service cost for next 10 years (to be mentioned as in attached Table-2), (3) The cashflow with interest income and balance in the pension system for future 10 years, (4) The financial correlation and correspondence including income and expense for the proposed pension system for next 10 years (to be mentioned as in attached Table-3).

As requested, Actuary usually provides this kind of result in the format supplied by the Ministry of Finance. Enterprises provide actuarial office with a format/example consisting of 3 tables of information. In producing these tables actuary follow the logic of the example provided by government offices.

Table-1:

\begin{tabular}{|l|l|l|l|l|l|l|}
\hline S1. & $\begin{array}{l}\text { Financial year } \\
(1)\end{array}$ & $\begin{array}{l}\text { Expected } \\
\text { retirees } \\
(2)\end{array}$ & $\begin{array}{l}\text { Gratuity } \\
\text { amount to be } \\
\text { paid } \\
(3)\end{array}$ & $\begin{array}{l}\text { Provident Fund } \\
\text { amount to be } \\
\text { paid } \\
(4)\end{array}$ & $\begin{array}{l}\text { Interest Provident Fund } \\
\text { amount to be } \\
\text { paid (5) }\end{array}$ & $\begin{array}{l}\text { Total amount } \\
\text { (6) }\end{array}$ \\
\hline 1 & & & & & & \\
\hline. & & & & & & \\
\hline. & & & & & & \\
\hline 10 & & & & & \\
\hline
\end{tabular}

Table-2:

\begin{tabular}{|c|c|c|c|c|c|c|}
\hline Sl. & $\begin{array}{l}\text { Financial year } \\
\text { (1) }\end{array}$ & $\begin{array}{l}\text { Expected } \\
\text { retirees } \\
(2)\end{array}$ & $\begin{array}{l}\text { Expected } \\
\text { Pension } \\
\text { payments } \\
\text { (3) }\end{array}$ & $\begin{array}{l}\text { Expected } \\
\text { Commutation } \\
\text { lump sum } \\
\text { payments } \\
(4)\end{array}$ & $\begin{array}{l}\text { Total payments } \\
\text { (5) }\end{array}$ & $\begin{array}{l}\text { Comment } \\
\text { (6) }\end{array}$ \\
\hline 1 & & & & & & \\
\hline . & & & & & & \\
\hline
\end{tabular}

Table-3:

\begin{tabular}{|c|c|c|c|c|c|c|c|c|}
\hline Sl. & Financial year (1) & $\begin{array}{l}\text { Initial asset } \\
\text { (2) }\end{array}$ & $\begin{array}{l}\text { Gratuity } \\
\text { amount to } \\
\text { be paid } \\
\text { (3) }\end{array}$ & $\begin{array}{l}\text { Provident } \\
\text { Fund } \\
\text { amount to } \\
\text { be paid } \\
\text { (4) }\end{array}$ & $\begin{array}{l}\text { Investment } \\
\text { income on } \\
\text { asset (5) }\end{array}$ & $\begin{array}{l}\text { Annual } \\
\text { total } \\
\text { amount (6) }\end{array}$ & $\begin{array}{l}\text { Pension } \\
\text { scheme } \\
\text { amount to } \\
\text { be paid } \\
\text { (7) }\end{array}$ & $\begin{array}{l}\text { End of the } \\
\text { year } \\
\text { Pension } \\
\text { fund size } \\
(8)\end{array}$ \\
\hline 1 & & & & & & & & \\
\hline . & & & & & & & & \\
\hline . & & & & & & & & \\
\hline 10 & & & & & & & & \\
\hline
\end{tabular}


This section are produced as per the requirements of the Ministry of Finance, and are submitted by pension seeking government office to support the request to introduce pension benefits for the employees of the respective government offices.

The demand as per attached Table-1 and Table-2 (from MoF) seems reasonable but not the Table- 3 . So, the points with respect to table 3 is that the information and calculations in this table make little sense in relation to actuarial perspectives because they do not reflect the running of a Gratuity or Pension Fund that is a separate Trust but separate trustee is another requirement of the set requirements of MoF. Hence, it is contradictory. Actuaries are never the less providing this as requested by the government offices as asked by MoF. However to include the following comments on the required Table 3 hereunder:

- The gratuity amounts to be paid (column 3 ) are the actual amounts to be paid to members on retiring. This follows the logic of the example provided. Actuarial observation is that this could alternatively be (a) the payments made into the Gratuity Fund with respect to future service accrual or (b) any deficit payments made into the Gratuity Fund (see Table-1, column 4) or (c) both a and b.

- The Provident Fund amounts to be paid (column 4) shown in the example provided do not take account of the Provident Fund accumulated for each prior year for the employees in question. It does not therefore provide a complete reflection of the money that would need to flow out of available funds in respect of each employee.

- Payments in respect of pensions (including commuted lump sums) shown in our table (column 7), was produced based on actuarial calculations. Actuaries have no scope to address it as there was no discernable logic to it. It was not an actuarial approach.

- The growth of assets shown ignores the fact that there will be liabilities remaining in the fund (with respect to members receiving pensions they have not commuted) and with respect to members that have not retired. These liabilities will grow at a similar pace to the asset growth shown. This means that the deficit in the pension scheme will also grow (all other things remaining equal), and looking at the asset only position, as this table does, is misleading.

\subsection{The Gray Point:}

The fact is there is no direct pension regulator or any regulator that intervenes, monitors; surveillances the employees' benefit schemes operation directly for both private and government. Moreover, there is no kind of pension supervisor exists within its regal footing and capacity to regulate this section for both domains. So, the entire system is functioning with no specifically relevant office under pension jurisdiction. In this circumstance the obvious questions are: 'Is it disciplined under its current regime?', 'Do other regulators supervise that and how extent within jurisdiction? For example, whether IDRA supervises all the insurance companies doing diligent towards these benefit scheme or do BSEC supervises whether its listed companies are compliant in this regard 'A Are there any standard to follow during regulation?'

Starting from the last question- Bangladesh has no its own set of exclusive accounting standards so far. So, it fully follows International Accounting Standard (IAS) that is wholesale trade and the name is Bangladesh Accounting Standard (BAS). The relevant number to the employees' benefit fund in this standard is Bangladesh Accounting Standard is 19 (BAS 19). Not all the audited report supplied by appointed/external audit firms covers this BAS 19 in regular basis. Although some reputed audit firms are sincere on this, but many audit firms hardly cover the points relevant of actuarial gain and loss under the capacity of BAS 19 in respect but qualifying their report and many enterprise are listed in Stock Exchange and facing this condition from appointed auditor and BSEC seemingly reluctant to this may cause a severe and extreme condition for both the employees of the private office and investors in the capital market. Hence, the absence of financial indiscipline prevailing in pension economics in Bangladesh as regulators are not paying attention on BAS 19 in the audited report made for both private and government offices for regular basis. There are 46 domestic private insurance companies of more than 10 years lifetime are listed in capital market. So, their regulators are BB, IRDA, BSEC. All these companies submit their qualified audit report to these regulators each year. But, a few among these companies' employees' benefit scheme have fully coverage on BAS 19. There are 30 banks listed in the capital market and $\mathrm{BB}, \mathrm{BSEC}$ are their regulators but not all the bank's audit report maintaining BAS 19 on regular basis. These short comes drive employee benefit into severe threat and then distinguishable financial risks to both employees and investors in those listed companies which are not compliant to BAS 19.

\section{Recommendation}


Set a new party for employees' benefit schemes and funds which will take all the action relevant to the employees' benefit scheme within its jurisdiction through enacting law, implementing strong IT department for strong support to store true membership data and its update time to time, appointing skilled and sound technical persons and positions etc. The numeric value of liability mostly depends upon the underlying assumption considered by actuary during valuation and the attitude of actuary towards the assumption basis consideration, which is a very sensitive point that relevant to the prudence, due experience, diligence, and consistency to the macroeconomic picture of the national economy considered by appointed actuary. So, the party should be with arsenals of knowledge and experience, sound to technical support which will act on the behalf of the government and assist to it. The party has to has scope to integrate other regulatory body and the relevant professional institutions like Accountant body, Actuarial body etc. So, this party is to be equivalent to other regulatory bodies like BB, BSEC, IDRA, RJSC etc. Hence the party be another regulatory body for specific dedication.

Institute of Charter Accounts of Bangladesh should take due measures so that accounting standards to be strictly followed by auditors regularly and also have to set some major measures in the case of violation of the standards and qualifying appropriate reports until a new regulator starts its journey.

The Security and Exchange commission should take stringent measure for the sake of public safeguard regarding their investment in the capital market through disallowing the questionable audit report that is inappropriate as per accounting standards in its capacity.

The Bangladesh Bank (Central Bank) should have reasonable measure in this regard through their BRPD department to observe whether the BASEL requirements are maintained regularly for the banks as these requirements are relevant to the interest on employees' benefit scheme.

\section{Conclusion}

This paper is indicative in the sense this reveals the ongoing haphazard activities in different types of employees' benefit schemes including financial risk of employees to their right, irregular performance from appointed auditor's in reporting in the light of BAS 19 in many companies, improper addressing to employees' benefit scheme by common regulators, misleading measures to actuarial valuation approach, and associated capital market investment risk for general investors, misleading requirements set for government offices by Ministry of Finance and the poor performance in policy making level due to readily absence of relevant regulator in the territory. This paper is also instructive in the sense it demands a potential and sound supervisory body as regulator to benefit the discipline of employees' benefit schemes.

As long as limitation is concern, this paper is based on couple of studies executed on couple of companies of different natures. Therefore, the comments, inference drawn from the case studies are not applicable for generic and the studies have a couple of limitations typically. Hence, the out comes from this study is not applicable for all the public and/or private organizations.

\section{References}

[1]. Act-Ed Study materials, CT5-Life Contingencies, (2011), The Actuarial Education Company, UK.

[2]. B. Benjamin, J.H. Pollard, (1993), $3^{\text {rd }}$ edition, The analysis of mortality and other actuarial statistics, Faculty and Institute of Actuaries, ISBN 0901066265.

[3]. Bowers, Newton L et al., (1997), Actuarial mathematics, $2^{\text {nd }}$ edition, Society of Actuaries, ISBN: 0938959468.

[4]. H.U Gerber, (1997), Life Insurance mathematics, $3^{\text {rd }}$ edition, Springer, Swiss Association of Actuaries, ISBN 354062242 X.

[5]. Act-Ed Study materials, ST-4, (2011), The Actuarial Education Company, UK.

[6]. Act-Ed Study materials, SA-4, (2011), The Actuarial Education Company, UK.

[7]. N. Alistair, Heinemann, (1977), Life Contingencies, ISBN 0434914401.

[8]. The tables supplied by Government Corporation.

[9]. Actuarial Reports on Pensions of different relevant government offices.

[10]. Actuarial Report on Gratuity of different relevant private offices.

[11]. Document of the circular issued by MoF, Bangladesh; Requirement for pension launching for autonomous, Corporation, etc government offices Circular Reference No. of (MoPoBi/Sha:Cro://Ortho-7/99-163) of dated: 09/08/1999.

[12]. Fundamentals of Private Pensions by McGill, Brown, Haley \& Schieber : University of Pennsylvania Press.

[13]. International Accounting Standard 19 (IAS 19) \& International Financial Reporting Standard (IFRS). 